\title{
Medical Waste Management and Control
}

\author{
Zarook M. Shareefdeen
}

American University of Sharjah, Sharjah, UAE.

Email: zshareefdeen@aus.edu

Received October $3^{\text {rd }}$, 2012; revised October 25 ${ }^{\text {th }}$, 2012; accepted November $26^{\text {th }}, 2012$

\begin{abstract}
Medical centers including hospitals, clinics and places where diagnosis and treatment are conducted generate wastes that are highly hazardous and put people under risk of fatal diseases. Although the understanding of medical waste management and control techniques is important, technical elective courses that are offered in undergraduate chemical, civil or environmental engineering place less emphasis on this area of education. In this paper, the meaning of medical waste, the risks of exposure, medical waste management regulatory acts, medical waste management procedures and control techniques are presented. The contents presented in this paper served as a supplementary material in an undergraduate elective course on waste management and as an educational guide for medical staff training on waste handling.
\end{abstract}

Keywords: Medical Waste; Medical Waste Act; Waste Management and Control

\section{Introduction}

Waste in general is any substance (solid, liquid, or gas) that has no direct use and is discarded permanently. A waste is considered hazardous if it exhibits any of the characteristics such as being flammable, reactive, explosive, corrosive, radioactive, infectious, irritating, sensitizing, or bio-accumulative [1]. Medical waste is limited to infectious, hazardous, and any other wastes that are generated from health care institutions, such as hospitals, clinics, dental offices, and medical laboratories [2]. The management of medical waste has been of major concern due to potentially high risks to human health and the environment. In the past, medical wastes were often mixed with household wastes and disposed in municipal solid waste landfills.

Hassan et al., 2008 [3] report a survey on Bangladesh hospitals that generate a total of $5562 \mathrm{~kg} /$ day of wastes, of which about $77.4 \%$ are non-hazardous and about $22.6 \%$ are hazardous. The average waste generation rate for the surveyed hospital is $1.9 \mathrm{~kg} / \mathrm{bed} /$ day or $0.5 \mathrm{~kg} / \mathrm{pa}-$ tient/day. The study reveals that there is no proper, systematic management of medical wastes except in a few private hospitals that segregate their infectious wastes. Some cleaners were found to salvage used sharps, saline bags, blood bags and test tubes for resale or reuse. In Bangladesh, proper medical waste management is a new phenomenon and government of Bangladesh is trying to develop a new and modern approach to deal with the medical waste properly. Project in Agriculture, Rural Industry, Science and Medicine (PRISM-Bangladesh), a reputed national NGO in Bangladesh, with the financial support from Canadian International Development Agency
(CIDA) has recently developed a disposal facility for low cost medical waste treatment and management in Dhaka City.

Similarly, the generation of medical waste in Korea has been increasing in quantity and variety, due to the wide acceptance of single-use disposable items (e.g. gloves, plastic syringes, medical packages, bedding, tubing, and containers) [4]. In recent years, increased public concerns over the improper disposal of medical waste have led to a movement to regulate the waste more systematically and stringently by the Korea Ministry of Environment. Waste minimization and recycling are still not practiced, thus significant amounts of medical wastes are to be disposed. Incineration is the main method of medical waste treatment in Korea.

In the United Arab Emirates (UAE), there are over 800 clinics and hospitals that generate hazardous medical wastes [5,6]. The main method of medical waste treatment in most countries of the Middle East is incineration; however, other techniques that produce less pollution are now being introduced. The literature shows numerous case studies on the mismanagement of medical wastes as described above for illustration purpose.

The objective of this paper is to introduce readers about the medical waste management regulatory acts, definition of medical wastes, risks of exposure, medical waste management procedures and control techniques.

\section{Medical Waste Tracking Act and Definitions}

The Medical Waste Tracking Act (MWTA, 1988) is the 
first act to regulate medical wastes [7]. It was implemented after life-threatening incidents occurred due to the lack of proper medical waste disposal systems. One example of such incident was on June 1987 when 12 children in Indianapolis, Indiana, played with vials they found in a dumpster outside a medical office. The vials were filled with blood, and two of them were infected with AIDS. After medical wastes were found washing up on several East Coast beaches, USEPA (US Environmental Protection Agency) prompted US Congress to enact the MWTA in 1988 [8]. The Act required EPA to create a two-year medical waste demonstration program.

For the purpose of the demonstration program, the MWTA: a) defined medical waste and those wastes to be regulated; b) established a cradle to grave tracking system utilizing a generator initiated tracking form; c) required management standards for segregation, packaging, labeling and marking, and storage of the waste; and d) established record keeping requirements and penalties that could be imposed for mismanagement. According to MWTA medical waste is "any solid waste that is generated in the diagnosis, treatment, or immunization of human beings or animals, in research, or in the production or testing of biologicals" [8,9].

The World Health Organization (WHO) has classified medical waste into different types: a) Infectious: material-containing pathogens in concentrations high enough to cause diseases on exposure. This includes waste from surgery, lab cultures, used dressings, and others. b) Sharps: disposable needles, syringes, blades, broken glasses. c) Pathological: tissues, organs, body parts, human flesh, blood and body fluids. d) Pharmaceuticals: drugs and chemicals that are returned, spilled, expired or contaminated. e) Chemical: waste resulting from diagnosis, or cleaning material. f) Radioactive: waste contaminated with radioactive substances used in diagnosis and treatment of diseases. g) Pressurized containers including gas cylinders; and h) Substances with high heavy metal content: broken mercury thermometers, blood pressure gauges. Infectious, pathological and sharps are the most dominant types of medical waste [10].

The definition of medical waste excludes waste containing microbiological cultures used in food processing, urine, saliva, and nasal secretions unless they contain blood. Like any household and office, medical facilities also generate general wastes such as paper and plastic that are not dangerous to human beings [9]. Medical waste such as sharps (i.e. needles, syringes, scalpels, etc.) can endanger human in a non-infectious way.

Depending on the institutions, the quantities of medical wastes produced vary [11]. Households are considered to be small quantity generators, while hospitals are considered to be large quantity generators $(>100 \mathrm{~kg} /$ month or more of medical waste). Medical wastes in- cluding infectious and sharp wastes account for about $35 \%$ of the total waste generated in hospitals. The remaining $65 \%$ of the wastes are non-infectious. Unlike industrial wastes which vary depending on the type of processes or sectors (i.e. chemical, petroleum, municipal etc.), medical waste compositions remain more or less the same.

Regardless of its quantity and where it is generated, medical waste has serious sometimes fatal effects on exposure. Medical staff, janitors, medical center visitors and patients are exposed to the risk of infection and diseases as a result of exposure. Thus, medical waste hazards and risks exist not only for the waste generators and operators, but also for the general community including children who play near disposal areas. The possible exposure pathways include direct contact, airborne transmission, contaminated water sources and the environment in general.

\section{Medical Waste Management Techniques}

There are several methods to minimize the hazards resulting from medical waste [10].

\subsection{Segregation}

Segregation is useful since it prevents the contamination of non-hazardous waste by the hazardous waste and making the whole waste stream hazardous. Thus, this method will reduce the toxicity and the volume of the waste stream. Moreover, segregation makes it easier to transport the waste. Waste is segregated depending on the quantity, composition, and the disposal method of the waste stream.

\subsection{Separating Different Categories of Medical Wastes}

In medical centers, infectious and pathological waste, and sharps are placed in different containers. The containers are labeled as "biohazard", closed, water tight and of uniform color for each type of medical waste throughout the medical center. The size of the containers depends on the volume of waste generated and the containers used are easy to handle and transport. For used needles specially designed containers are used.

The system for segregation, packaging, labeling and marking involves separating the medical waste into categories, as described. The packaging is done in colored bags [12]. For example, yellow plastic bags are used for infectious medical waste that is meant to be disposed by means of incineration or deep burial in landfill. However, if they are to be treated by autoclave or microwave, they are placed in red plastic bags or containers. In steam autoclaving, the waste is decontaminated by the effects of the saturated steam at elevated temperatures and high 
pressure. This method is not applicable for pathological, chemotherapy and radioactive wastes.

Hazardous waste packaged in either blue or white transparent bags is usually treated by autoclave, microwave, chemical treatment and shredding, or by landfilling. As for labeling and marking, medical wastes are popularly known to have the bio-hazard symbol. Both the packaging and labeling are adopted worldwide. The difference is in treatment methods [12].

\subsection{Disinfection}

In order to reduce the toxicity of some medical wastes, chemical disinfectants (i.e. chlorine dioxide, sodium hypochlorite, or per acetic acid) are sometimes used. For solid wastes, disinfection is effective if only waste materials are shredded. In some cases, the disinfectants themselves are hazardous, thus it is not recommended for treating pharmaceutical, chemical and some types of infectious waste.

\subsection{Incineration}

Incineration is the process of destructing waste by burning it at elevated temperatures in furnaces. The process removes hazardous materials, reduces the mass and volume of the waste and converts it into ash that is harmless. Incineration is suitable for wastes that are $60 \%$ combustible. Incineration is suitable for pathological and infectious waste or sharp wastes. Incinerators exist in several different types; each type has a specific function. A mobile incinerator called "drug terminator" is used for disposal of pharmaceuticals. A diesel fired medical waste incinerator called "MediBurn" treats pathological and infectious waste in small medical facilities, and laboratories [13]. This unit is portable and easy to operate and it can incinerate everything from laboratory waste to animal remains.

The advantage of incineration process is that the volume of the waste that will remain for disposal will be reduced by 50 - 400 times [14]. Incineration has a significant advantage of decreasing the volume of the wastes; however its disadvantages include high costs, smoke generation and pollution risks. Incinerators used in hospitals produce more furans and dioxins than incinerators used in municipality. This higher concentration of furans and dioxins are due to a) frequent startups and shutdowns; b) less stringent emission controls; c) poor combustion control (e.g., waste mixing and oxygen controls); and d) differences in the waste feed composition as compared with municipal solid waste [15]. Incinerators are usually built with a chimney to reduce the smoke and its effect on pollution. Moreover, incinerators are usually located at least $100 \mathrm{~m}$ away from the medical center in order to reduce the effect of smoke. A pit below the incinerator is usually available in order to collect the ashes. Incineration is one of the most efficient methods of disinfecting medical waste.

\subsection{Disinfection by Plasma}

In this process, low temperature plasma which is produced by the plasma generator using air as working fluid organizes a combustion process. The medical waste is constantly mixed, thus it maximizes the heat and mass exchange which saves any energy loss. The heat produced is used as an additional heat source in the process. This technology eliminates the formation and release of irregular forms of $\mathrm{NO}_{\mathrm{X}}$ and high-toxic substances (i.e. dioxins) into the atmosphere. Another main advantage is that it has low consumption of energy compared to other mineralization (i.e. combustion) processes [14].

\subsection{Emerging Technology}

A new technology for management of hazardous medical waste that transforms the regulated medical waste into municipal solid waste is recently introduced. This method involves shredding and grinding the infectious medical waste bags via sharp cutting blades that are installed within the vessels. The blades rotate around 1750 revolutions per minute and the volume of the shredded waste is reduced by $80 \%$ [16]. The steps included in the process are loading, shredding, heating, sterilization, cooling, draining, vacuum and unloading. The whole process is enclosed in a compact system and there is no intermediate handling of the waste within the process. Due to the compact size, this system can easily be used for on-site treatment of the waste and installed in hospitals. This will reduce the transportation costs of the medical wastes. In terms of environmental aspects, it is a clean and chemical-free technology and does not have any hazardous emission or radiation [16]. This method is economical and environmentally friendly and is reliable in terms of ease of use and maintenance. This technology is currently practiced in the middle-eastern countries such as Iraq, Jordan, Kuwait, Lebanon, Syria and UAE.

Similarly, a team of engineers in Idaho National Laboratory, USA have invented a new patented technology that helps in better management and treatment of the medical wastes. Based on this technology, Med-Shred, Inc., (Texas, USA) has developed a mobile shredding and chemical disinfecting machine that is aimed for on-site treatment of hazardous medical waste [17]. The machine converts the medical waste into disposable municipal waste using shredders that shred the waste into smaller particles which are then wetted with disinfectant spray and immersed in a disinfection solution. The wet waste is then dried using a hot off-gas in a drying chamber. Considering the number of clinics and hospitals in 
middle-east, this method will be very successful if utilized, as it can treat the medical waste on-site which helps in better management of wastes.

\section{Conclusion}

Medical wastes are highly hazardous and put people under risk of fatal diseases. The understanding of medical waste management and control techniques is important. In this paper, introductory materials on the definition of medical waste, medical waste management regulatory acts, the risks of exposure, medical waste management procedures and control techniques are presented.

\section{Acknowledgements}

The author acknowledges feedback of chemical engineering students from the American University of Sharjah (AUS) and medical staff of Al-Qassimi Hospital, Sharjah, UAE.

\section{REFERENCES}

[1] M. D. LaGrega, P. L. Buckingham and J. C. Evans, "Hazardous Waste Management,” 2nd Edition, Mc-Graw Hill, 2001.

[2] US Congress, Office of Technology Assessment, "Issues in Medical Waste Management-Background Paper," US Government Printing Office, Washington DC, 1988.

[3] M. M. Hassan, S. A. Ahmed, K. A. Rahman and T. K. Biswas, "Pattern of Medical Waste Management: Existing Scenario in Dhaka City, Bangladesh,” BMC Public Health, Vol. 8, 2008, p. 36. doi:10.1186/1471-2458-8-36

[4] Y.-C. Jang, C. Lee, O.-S. Yoon and H. Kim, "Medical Waste Management in Korea," Journal of Environmental Management, Vol. 80, No. 2, 2006, pp. 107-115. doi:/10.1016/j.jenvman.2005.08.018

[5] UAE Yellow Pages, “Clinics and Hospitals,” 2010. http://www.yellowpages.ae/category/clinics-/ http://www.scribd.com /doc/4100881/

[6] “Middle East Health Care Intelligence,” 2010. http://biomedme.com/uae/dubaisclemenceau-medical-centeramongst-top-ten-best-hospitals-for-medical-tourism_6555. html
[7] Medical Waste Management Act (MWMA), El Dorado County, 2010. http://www.edcgov.us/Government/EMD/Hazardous Materials/ Medcal Waste Management Act.aspx

[8] US Environmental Protection Agency, US Environmental Protection Agency, "Medical Waste Tracking Act of 1988," 2010.

http://www.epa.gov/wastes/ nonhaz/industrial/ medical/tracking.htm

[9] WasteMed, Types of Medical Waste, 2010. http://www.wastemed.com/types.htm

[10] WHO, (The World Health Organization), "Waste Management at Medical Centers,” 2010. http://www.who.or.id/eng/contents/aceh/wsh/books/es/ES 08CD.pdf

[11] J. M. Alhumoud and H. M. Alhumoud, "An Analysis of Trends Related to Hospital Solid Wastes Management in Kuwait," Management of Environmental Quality: An International Journal, Vol. 18, No. 5, 2007, pp. 502-513.

[12] Madhya Pradesh Pollution Control Board, "Handling of Bio-Medical Waste,” 2010. http://www.mppcb.nic.in/Bio_Categories.htm

[13] Innovative Environmental Product, 2010. http://www.elastec.com/ portableincinerators/ drugterminator/

[14] G. Rutberg, N. Bratsev, A. Safronov, V. Surov and V. Schegolev, "The Technology and Execution of Plasma Chemical Disinfection of Hazardous Medical Waste," IEEE Transactions on Plasma Science, Vol. 30, No. 4, 2002, pp. 1445-1448.

[15] Waste Treatment Technology News, United States Environmental Protection Agency, Environmental Protection Agency Issues, Draft Dioxin Assessment, 2010.

[16] W. Lersner, The Process and Device for the Disposal of Medical Waste, “Canadian Patents Database,” Patent Number 2079003, 2007. http://www.ecolotec. com/patents.html

[17] N. R. Soelberg, R. A. Rankin, K. M. Klingler, C. W. Lagle and L. L. Byers, "Eliminating Medical Waste Liabilities through Mobile Maceration and Disinfection," WM'06 Conference, Tucson, 26 February-2 March 2006. http://www.inl.gov/technicalpublications/Documents/ 3394936.pdf 